Chapman University

Chapman University Digital Commons

10-18-2018

(In)Visible Men on Campus: Campus Racial Climate and Subversive Black Masculinities at a Predominantly White Liberal Arts University

Quaylan Allen

Follow this and additional works at: https://digitalcommons.chapman.edu/education_articles

Part of the Curriculum and Social Inquiry Commons, Educational Assessment, Evaluation, and Research Commons, Educational Sociology Commons, Higher Education Commons, Liberal Studies Commons, Other Education Commons, Race and Ethnicity Commons, and the Social and Philosophical Foundations of Education Commons 
(In)Visible Men on Campus: Campus Racial Climate and Subversive Black Masculinities at a Predominantly White Liberal Arts University

\section{Comments}

This is an Accepted Manuscript of an article published in Gender and Education, volume 32, issue 7, in 2020, available online at https://doi.org/10.1080/09540253.2018.1533924. It may differ slightly from the final version of record.

\section{Copyright}

Taylor \& Francis 
(In)Visible Men on Campus: Campus Racial Climate and Subversive Black Masculinities at a Predominantly White Liberal Arts University

\author{
Quaylan Allen, Ph.D. \\ Assistant Professor \\ Attallah College of Educational Studies \\ Chapman University \\ One University Drive \\ Orange, CA 92866, USA \\ qallen@,chapman.edu
}

714.455 .9868 


\title{
(In)Visible Men on Campus: Campus Racial Climate and Subversive Black Masculinities at a Predominantly White Liberal Arts University
}

\begin{abstract}
In this paper, I examine how Black male college students attending a predominantly White liberal arts institution in the USA perceive the campus racial climate and make sense of their (in)visibility at the university. Drawing upon poststructuralist theories of gender and critical race theory, I analyze the ways in which they managed race, gender and sexuality within university spaces, giving attention to their agency in performing a range of masculinities in response to and in anticipation of campus-based racism and racialized discourses. By situating their gendered performances within the context of the campus racial climate, I argue that universities are sites of racial and gender socialization where dominant ideologies of Black masculinities are imposed, and where ontological installments of gender play out in ways that can impact Black males' inclusion on campus. Suggestions for the improvement of Black male higher education success will be discussed.
\end{abstract}

Keywords: Black masculinities, microaggressions, campus racial climate, higher education, visual research

Word Count: 8,990 


\section{(In)Visible Men on Campus: Campus Racial Climate and Subversive Black Masculinities at a Predominantly White Liberal Arts University}

\section{Introduction}

Black students in the United States currently make up $15 \%$ of the nation's undergraduate population, and though most Black college students (almost 70\%) will attend public 4 or 2-year institutions, over 14\% of Black undergraduates attend private non-profit universities and colleges (Musu-Gillette et al. 2017). Most Black college students obtaining a 4-year degree will attend what is known in the U.S. as a Predominantly White Institution (PWI) and studies find that Black students attending PWI's are often immersed in campus climates that are racially hostile to students of color (Feagin, Vera, and Imani 1996; Hurtado 2015; Johnson et al. 2014). Campus racial climate refers to the overall racial environment of the university, which might include its racial composition, curricular and co-curricular diversity, the frequency of racial incidents and the institutions response to racial inequities (Harper and Hurtado 2007; Hurtado 2015; Solórzano, Ceja, and Yosso 2000).

A poor racial climate negatively impacts the academic opportunity and success of Black students (Steele 1997; Shih, Pittinsky, and Ambady 1999; Smith, Hung, and Franklin 2011; Landrine and Klonoff 1996), and Black students attending PWI's are most likely to report the most experiences with racial discrimination on and off campus (D'Augelli and Hershberger 1993; Harris 2003). The racial discrimination that Black students report are largely within the taxonomy of racial microaggressions, which are defined as the subtle forms of discrimination that denigrate marginalized communities (Pierce et al. 1978). Racial microaggressions on college campuses are felt through environmental cues and verbal or non-verbal hidden messages that serve to invalidate Black men and their presence on campus. For example, many Black students 
attend universities in which White students outwardly express resentment and hostility towards students of color and policies that aim to increase enrollment of Black students (Lewis, Chesler, and Forman 2000; Bonilla-Silva and Forman 2000). Black students often have their presence on campus questioned by their peers, they are made to feel invisible in campus spaces, and are expected to assimilate into White culture (Turner 1994; Lewis, Chesler, and Forman 2000; Smith, Yosso, and Solórzano 2007).

Microaggressions might also be experienced at particular intersections of race, gender, or sexual orientation. For instance, Black males on predominantly White campuses are assumed to be cisgender, heterosexual, athletes, unintelligent, deviant, or sexually promiscuous (Hall et al. 1978; Majors and Billson 1992). These stereotypes shape the way Black men are feared, avoided, and exoticized by White peers, and the way they experience hypersurveillance and over-policing on campus (Smith, Yosso, and Solórzano 2007; Solórzano, Ceja, and Yosso 2000; Feagin 1992; Solórzano, Allen, and Carroll 2002; Wilkins 2012b). Thus, microaggressions such as racial profiling and hypersurveillance occur at particular intersections of race and gender for Black men as they are disproportionally profiled and surveilled because they are both Black and male . Race, gender and sexuality intersect in other ways for Black gay men, as many will also experience sexual orientation microaggressions through homophobic language and heteronormative expectations that attempt to regulate their gender and sexual expressions (Woodford et al. 2013; Nadal et al. 2011; Harris 2003). Furthermore, Black gay men also report feeling racially excluded from White LGBTQ+ communities on campus but also ostracized by some heteronormative Black spaces on campus (Nadal et al. 2011; Strayhorn and Tillman-Kelly 2013). 
Within the classroom, Black students at PWI's are academically stereotyped and assumed to be less intelligent than their classmates (Gleditsch and Berg 2017; Lewis, Chesler, and Forman 2000; Fischer 2010). They are often avoided by their classmates during group projects or activities, and as one of few Black students in a class, they are expected to speak on the behalf of all Black students on issues of race (Lewis, Chesler, and Forman 2000; Henry, Fowler, and West 2011; Solórzano, Ceja, and Yosso 2000). Informal and out of class interactions with faculty are considered important high impact practices and a valuable source of social capital (Waiwaiole, Bohlig, and Massey 2016). However, Black students report having negative interactions with faculty, and research shows that White faculty tend to hold lower academic expectations for Black males (Harper 2009; Smedley, Myers, and Harrell 1993; Solórzano, Ceja, and Yosso 2000), and avoid contact or limit their interactions with Black male students (Feagin 1992; Kim 2010; Comeaux 2013). However, some studies have shown that faculty with more lived experiences with people of color tend to have greater interactions with Black males (Palmer and Gasman 2008; Gleditsch and Berg 2017), and Black males who describe positive interactions with their faculty demonstrate higher levels of academic self-efficacy and perform better in college (Karl 2013; Fischer 2010).

When Black students articulate their concerns about the racial climate of their campuses, their concerns are often dismissed or suppressed (Jones and Reddick 2017; Strong 2013). The rise of Black student activism on the campuses like the University of Missouri and Evergreen State, for example, are responses to a poor racial climate and to what scholars refer to as institutional negligence regarding a university's racial commitments (Harper and Hurtado 2007; Jones and Reddick 2017). Furthermore, a poor racial climate has shown to negatively impact the sense of inclusion and community of Black students, academic self-concept, academic 
performance and graduation rates (Steele 1997; Shih, Pittinsky, and Ambady 1999).

Additionally, the cumulative effect of racial microaggressions contributes to a range of psychological stressors and trauma related symptoms that limit the academic and social success of Black students (Smith, Hung, and Franklin 2011; Landrine and Klonoff 1996). However, a positive racial climate has shown to contribute to a higher sense of inclusion and community for Black students, increases self-efficacy, higher academic performance and overall positive effects for all students on campus (Fischer 2010; Park, Denson, and Bowman 2013).

There is an emerging area of literature on Black males who succeed within these institutions and how they respond to a predominantly White campus climate. For example, research on Black male achievers describes the social and cultural capital Black males draw upon in order to succeed in college (Strayhorn 2010; Harper 2008). Other studies have examined prosocial and counter-hegemonic Black masculinities performed on campus, and how Black men respond individually or collectively to campus-based racism (McClure 2006; McGee and Martin 2011; Harper and Quaye 2007). For instance, McGee and Martin's (2011) study examined how Black mathematics and engineering students engaged in stereotype management in order to proactively counter and resist racist conceptions of their masculine identities. Other studies highlight how Black students create counterpaces of solidarity on campus, respond to racial encounters in college, and engage in political activism toward racial justice (Jones and Reddick 2017; Hope, Keels, and Durkee 2016)

These studies have contributed greatly to our understanding of Black male college life, but still less is qualitatively known about Black men attending predominantly White liberal arts universities and how they might respond to the campus racial climate. Furthermore, colleges and universities are understudied institutions of social and cultural reproduction, and with increasing 
enrollments of students, they should be studied as important sites of racial and gender socialization for Black men.

In this paper, I present narrative and visual data from Black men attending a PWI, and share how they perceive the campus racial climate and make meaning of the race-gendered microaggressions they experienced on a predominantly White campus. I also analyze the ways in which they managed race, gender and sexuality within university spaces, and situate their gendered performances within the context of the campus racial climate. I argue that universities are sites of racial and gender socialization where dominant ideologies of Black masculinities are imposed, and where ontological installments of gender play out in ways that can impact Black males' sense of inclusion on campus. Attention will be given to their agency in how they perform a range of masculinities in response to and in anticipation of college-based racism and racialized discourses.

\section{Theoretical Frameworks}

This paper draws upon poststructuralist theories of gender and critical race theory in an examination of Black men's gendered experiences on predominantly White college campuses. Poststructuralist gender scholars argue that gender is a socially constructed concept that exists via systems of symbolic practices and performances that are constantly informed by and through relationships of power (Gardiner 2005; Butler 1988). Butler (1988) in particular posits that gender is brought into being performatively, that is to say gender is constructed discursively and involves the subsequent repetition, citation and iterability of particular gender norms that create the preconditions by which masculinities are produced. Further, the repetition of gender norms are performed within dominant regimes of truth that support certain masculinities over others. Through self-regulation men demonstrate acculturation or subversion to hegemonic or 
subcultural definitions of masculinity, enacting the "correct" masculine performance at the right time and place (Whitehead and Barrett 2001).

Critical race theory and its scholars assert that racism is endemic in American society. As an interdisciplinary legal theory, critical race theory foregrounds race and its intersectionality at the center of analysis (Bell 1992; Crenshaw 1993). Thus critical race theory is also useful in the examination of Black masculinities in college as Black American men exist in a society in which racism is endemic, and perform gender within and through racialized regimes of truth (Foucault 1979). Black men are both idolized and feared, and as the hypervisible racialized 'other', their polemical bodies are seen as both a threat and a commodity to a White, patriarchal, capitalist society (Saint-Aubin 2002). As such, Black masculinities might be understood as a collection of diverse performances constrained by the social anxiety and fear of Black men, and mediated by the state through particular hegemonic, discursive practices (Marriott 1996; Hall et al. 1978). In other words, though Black masculinities are indeed diverse, they are also expressively constrained by the endemicity of racism and the correlative ontologies of Black male identity that limit when and where Black men can perform certain masculinities.

Educational institutions are contested locations of social and cultural reproduction (Bourdieu 1977), and as sites of gendered reproduction, colleges are spaces in which Black masculinities are learned and practiced (Dancy 2011; Strayhorn and Tillman-Kelly 2013). Predominantly White college campuses in particular, are precarious locations in which Black men learn and perform gender, and many Black men will do so within inimical campus racial climates. On these campuses Black males are academically and sexually stereotyped (Hall et al. 1978; Majors and Billson 1992), are feared and avoided, and are subject to hypersurveillance and 
over-policing (Smith, Yosso, and Solórzano 2007; Solórzano, Ceja, and Yosso 2000; Feagin 1992; Solórzano, Allen, and Carroll 2002; Wilkins 2012b).

A poor racial climate in which Black men experience these types of microaggressions sets the context in which dominant ideologies of Black masculinities are imposed, and where ontological installments of gender play out. In other words, a poor racial climate not only impacts Black male's sense of inclusion, engagement and educational opportunity, but also contributes to the gender socialization of Black college men. Black men are also agents in their gender socialization on college campuses and certainly learn and engage in an array of masculine performances (Harper and Quaye 2007; Harris, Palmer, and Struve 2011; Strayhorn and TillmanKelly 2013) including those that challenge hegemonic notions of Black male identity (McGuire et al. 2014; Strayhorn and Tillman-Kelly 2013). Still, less is known about how Black men might learn and engage in masculinities that respond to the nature of the campus racial climate (McClure 2006; Jackson and Wingfield 2013) and contest hegemonic conceptions of their racialized masculinities.

\section{Methodology}

Data collection and analysis. Purposive and snowballing sampling strategies were used in recruiting participants who identified as Black, male and a current undergraduate or graduate student (Goetz and LeCompte 1984). Recruitment letters and emails were distributed through university affiliated listservs. Participants were provided verbal explanations of the study and received written consent forms explaining the purpose, procedures, risks, benefits and their right to withdraw.

Each participant completed a demographic survey and took part in four in-depth qualitative interviews conducted between 2015-2016. Critical race theory methodology informs 
the logic of these interviews as tenets of the theory seek to challenge dominant ideologies and center the experiential knowledge and counterstories of people of color (Solórzano and Yosso 2002). Black men's counterstories are critical in contesting majoritarian narratives that position Black male students as deviant, anti-intellectual, and culturally deficient (Bell 1992; Solórzano and Yosso 2002; Smith, Yosso, and Solórzano 2007; Howard, Flennaugh, and Terry Sr. 2012). Three of the interviews were open-ended and semi-structured modeled in the fashion of Siedman's (1991) three-interview series. The first interview focused on their personal and K-12 educational biographies. The second interview focused on their college and work experiences, and the third interview concentrated on race, manhood and masculinities.

The fourth interview was conducted through a photovoice project, which is a participatory visual methodology. Visual research involves the production and use of imagery, visual data, and visually-oriented materials in research and applied activities (Margolis and Pauwels 2011). The photovoice project asked participants to visually document issues or topics that were important to them. The images and videos produced from the photovoice project were used to elicit narrative responses in a visual elicitation interview. This participatory visual method has been used to privilege the insider voice and provide an emic understanding of issues of concern to marginalized communities, though the method is rarely used with Black male populations (Wang and Burris 1997). The narratives and select photos presented in this study are thus significant because they provide an emic understanding of Black men's college experiences through counter-storytelling and visual repositioning (Smith, Yosso, and Solórzano 2007).

All of the interviews were audio recorded and transcribed. Analysis of the data followed a qualitative interpretive approach (Erickson 1986) and was conducted using Nvivo qualitative data analysis software. First and second cycle coding methods were used on the data corpus, and 
key linkages among the different forms of data were identified. Initial assertions were tested against confirming and disconfirming evidence, and were organized into major themes and subthemes. Finally, I employed member-checking (Lincoln and Guba 1985) to obtain an additional level of validation, by asking participants for feedback on final themes and overall findings. During member checking, students provided the pseudonyms used in this paper.

Participants and Setting. This study included 13 Black men, eight from middle-class families and five from working-class families. Some of the students attended private high schools but the majority attended public schools, and all those who attended public schools had completed at least one upper ability course. All 13 students maintained college GPA's over 3.0 and are generally considered academically successful. 12 of the participants use he/him pronouns and one uses he/him, she/her pronouns. Eight students identify as heterosexual, four identify as gay, and one as bi-sexual.

The setting is a private liberal arts university located in the western United States. The university's student population consists of roughly 8,000 students of which almost $80 \%$ are undergraduates. The university is located amongst some of the wealthiest cities in the United States, with tuition costs of roughly $\$ 50,000$ a year. For some of the participants, the cost of tuition is a constant source of stress, and all of the students hold part-time employment, with some holding multiple jobs. Participants who attended predominantly White private high schools felt the social transition to the college was a bit easier for them, though all students expressed frustration with the lack of campus diversity. Black students account for under $2 \%$ of the student population, and Black people in general only make up $2 \%$ of the population in the surrounding county. 
At the time of the study, the university did not have a cultural center despite decades long requests from students for such a space. Beyond the Black student organization, there are few resources or programs on campus that directly support the recruitment, social integration and educational success of Black students. Furthermore, despite the small population of Black people in the surrounding county, the local human relations commission consistently reports that the vast majority of hate crimes are targeted toward Black people. Thus, regardless of economic status, Black students who attend the university and interact with the local communities find themselves in highly integrated settings where racialized interactions are not uncommon.

\section{(In)Visible Masculinities on Campus:}

In this section I begin the argument that predominantly White universities are contested sites of racial and gender socialization where dominant ideologies of Black masculinities are imposed, taken up and resisted. Racial stereotypes about Black men shape the way White peers fear, exoticize and objectify particular Black masculinities, and the way Black men experience hypersurveillance and over-policing on campus (Smith, Yosso, and Solórzano 2007; Solórzano, Ceja, and Yosso 2000; Feagin 1992; Solórzano, Allen, and Carroll 2002; Wilkins 2012b).

These factors contribute to a hostile campus racial climate for Black men and often sets the stage in which Black men perform a range of masculinities. As a numeric minority on campus, and operating within a discourse of Black male otherness, participants in the study described a fishbowl experience in which they often felt both invisible and hypervisible at the same time. For instance, Reg explained how his presence on campus is rendered invisible:

I feel like I'm the invisible man on campus, because people don't really speak or look at you and just keep walking. Especially if you look or dress a certain way you know you don't fit 
into their everyday norm, then you know they're not going to really notice you. So I just go on about my business. I don't really stick around and interact with other people just because I feel like I'm invisible.

Reg described his invisibility in a metaphorical sense in that his identity as a Black male, and his presentation of self sometimes causes members of the campus community to avoid or ignore him, rendering him as invisible. Black men in public spaces are often feared by Whites (Day 2006; St. John and Heald-Moore 1995) and Black men attending PWI's are often subject White anxieties.

Fear and anxiety of the presence of Black bodies on campus also contributed to the panoptical nature of the university in which Black men described feeling hypervisible as one of few Black bodies on campus. Students talked about constantly "getting looks" from gazing peers as they walked through campus and explained how they often avoided walking through heavily populated student gathering locations. The surveillance of their bodies sometimes led to having their presence on campus called into question. For example, Isaiah explains:

I remember one of the first times I was on campus, just exploring the campus a little bit. I wasn't dressed up, I was in casual clothes I felt like wearing, and someone asked me, "Are you lost?" Not, "Are you lost? Do you need help finding the building," but, "Why are you here?"

These racial microaggressions exemplify how many minoritized groups on campus are often made to feel like what Turner (1994) refers to as "guests in someone else's house", and how a poor campus racial climate might limit which Black masculinities are acknowledged as legitimate. 
Furthermore, the surveilling nature of the campus extended beyond the gaze of their peers as each participant described their encounters with campus and local police. The students' presence on campus and in the local community were regularly questioned by law enforcement and participants were often asked to present identification to prove their student status. Jay Blaze shared how he had been racially profiled at his on-campus job:

As I was walking around, this public safety officer he just kept following me. I finally said, "I work here!" He gets out of his car and he's like, "Oh we got a call. Somebody called saying there was a Black guy walking around. We didn't know if you were a student or you were just somebody from off the street." I was just like, "Man, I work at the front desk. Here's my ID." They're very surprised every time. Jay Blaze noted that this event has occurred multiple times and each time he presents his identification, police are surprised that he is a student. For the students in the study, the hypervisibility and surveillance they experienced as a numerical minority and racialized "other" points to the panoptical nature of the campus racial climate. The campus racial climate then contributes to Goffman's (1959) notion of the front stage, which is the social context in which Black men's masculine performances are acted out and where normalizing judgements of Black male deviancy are imposed (Noguera 2003). Furthermore, it is within the hidden curriculum of the campus racial climate that Black men learn how their bodies will be policed through ideological and repressive functions of the university (Margolis 2001).

Braxton's photovoice interview in particular, portrayed the role policing plays in his gender socialization. He photographed the side profile of a local police patrol vehicle (see figure 1), which represented a common theme among the photovoice projects - Black men's concerns with state violence and repressive force against Black bodies. Public discourse and habitual visual 
imagery of the over-policing and deaths of unarmed Black men by law enforcement is the context for Braxton's photo. He discusses the way racialized surveillance, both at large and within the private spaces of the university, contributes to his own masculine anxieties:

When we see a police car, there's always that "What if?" factor. There's that trepidation that sets in, you tense up, you get uncomfortable. I have to think about "Am I doing this? Am I doing that? What am I wearing? What music am I playing? Where am I driving? How fast am I going? Do I look like somebody else?"

\section{[Insert Figure 1 Here]}

Braxton described his concerns about racial profiling as an embodied experience, producing physical and psychological responses. The concern of being racially profiled also requires him to consider regulating his masculine performances in certain contexts to avoid hegemonic assumptions of Black male deviance. The hypersurveillance and racial profiling of Black men on college campuses relies on a hegemonic performativity of Black masculinity in which statesupported ontologies of Black deviance and otherness are installed onto the bodies of Black men. The surveilling acts described by the men and their general experiences of (in)visibility on campus are embodiments of the types of racial and gender socializing practices experienced at the university. These socializing practices also implicate the university as a contested site of cultural reproduction, where both ideological and repressive forces are drawn upon in the reproduction of Black men as the deviant 'other'. Amidst the campus climate of this PWI, Black men encounter dominant regimes of truth and negotiate how they might take up or subvert such conceptions of their race-gendered identities.

\section{Subversive Masculinities: Code switching, repositioning and resisting on campus}


Student success in postsecondary settings is highly correlated with the institutional environment, including its racial climate, and Black students are more likely to report more incidences of racial discrimination (Harper and Hurtado 2007; D'Augelli and Hershberger 1993). Students in the current study similarly described a poor racial campus climate. Within this context, however, Black men demonstrate agency in how they negotiate, resist or take up hegemonic conceptions of their identities, and did so by engaging in subversive Black masculine performances. Similar to other Black college men (Feagin, Vera, and Imani 1996; Jackson and Wingfield 2013; McGee and Martin 2011) this was partially accomplished by how they managed their race-gendered identities in university spaces as resistance to the microaggressions encountered on campus. This involved the practices of code switching, repositioning themselves against deficit views of Black males or by responding directly to the university's racial climate in deliberate ways.

Code switching. The students in this study were well aware of the larger stereotypes and fears of Black men. Similar to other Black college men (Dancy 2011), students' doubleconsciousness as well as their own racial socialization seemed to contribute to how they managed race on campus. For example, the topic of code switching was commonly discussed among the students with most describing their daily code switching practices. Code switching is generally defined as the process of using two or more languages or linguistic repertoires in conversation (Greene and Walker 2004). For most of the men in the study, code switching was used as a linguistic presentation of self that distinguished them as different from larger Black male stereotypes. Apollo describes when and how he code switches:

When I'm around mostly White people I try to act a little more polite. I have a good vernacular. I think sometimes that they look at that and they're like "he's not the 
stereotypical Black guy. He's speaking properly. He's not saying nigga every other sentence." I've gotten that hint from a lot people, like "he's kind of different from the norm."

Code switching was a practice that many of the men explained they had learned from family members as a way to navigate integrated spaces. Yosso (2005), a critical race theorist describes these types of practices as the linguistic and navigational capital that communities of color draw upon to resist racial marginalization. By code switching, students perform gender in ways that might deflect racial stereotypes. In this sense, code switching might also be considered a type of racial dramaturgy where Black college men perform certain masculinities that will be culturally accepted within public settings, or what Goffman refers to as the front stage (Goffman 1959). These performances though, are conducted on a university "stage" where Black male bodies are over-surveilled and disciplined under normalizing judgements of Black pathology. Code switching then, is a form of racial passing, at least in the metaphorical sense, in that Black men recognize their politicized positionality and perform masculinities that allow them to pass as "different from the norm" in particular moments .

Repositioning. In a similar fashion to code switching through language, the men in the study managed the racial climate on campus through particular presentations of self as a way to reposition themselves against racial stereotypes. Students discussed how they would stylize their bodies by wearing fashionable professional attire on campus or avoid wearing hooded sweatshirts to deflect any assumptions of their criminality. Within the classroom students managed the racialized academic expectations of Black men by establishing themselves academically among their faculty and peers. As typically the only Black person in the classroom, it was important for the students to make it clear to others that they belonged and deserved to be 
at the institution. Students indicated that this was generally done early in the semester and involved practices such as sitting near the front of the class to make a good first impression. Jay Blaze explains that when he asserts his position in the class "I feel it's gratifying. I'm making a statement. I'm seeing their confirmation of the statement I made and it's a big deal to me." Braxton elaborates on why establishing himself in the classroom is important:

You have to establish yourself as who you are and make a presence. Once that's done you are put on an equal level with the rest of the students. I feel that once my professors get over the fact that I can speak very well, I'm smart, they're like, "Oh wow!" It's like seeing a zoo animal do a trick or something like that. After that, they're over it.

Establishing their academic prowess in the classroom was intended to subvert hegemonic ontologies of Black male intelligence, and like other Black college men (McGee and Martin 2011) allowed the students to dispel racial stereotypes and feel like they leveled the playing field within the classroom.

However, students' experiences with repositioning were not all the same. Isaiah discussed how faculty sometimes misinterpret his assertiveness in the classroom as aggression. Isaiah explains:

I know that Black men are perceived as very aggressive. But because I'm gay, or because I have some feminine qualities, my "aggressiveness" becomes sassy. "Oh, you're being sassy." "No, I'm just telling you exactly what I think and feel." If I was a White man I would be seen as "passionate" but instead I'm being dramatic. What the fuck? I was like, "There's no difference."

In schools and colleges, the behaviors of Black men are often interpellated as aggressive or intimidating by their teachers and faculty (Davis 2003; Shirazi 2016), and within predominantly 
White settings, these stereotypes serve as constraints to Black men's emotional and gender expressions (Jackson and Wingfield 2013; Wilkins 2012a). As Isaiah points out, Black men's assertiveness in the classroom is not affirmed in the same way as White men's. Furthermore, race, gender, and sexuality intersect in this particular type of microaggression for Isaiah. His assertiveness in the classroom is not only misinterpreted as aggression, but because of his sexuality and gender expression, his aggression is gendered as feminine or "sassy". Thus, this particular microaggression not only imposes dominant assumptions of Black male aggression, but also serves to reinscribe cisgender and heteronormative expectations of Black gay men's gender performance (Nadal et al. 2011; Harris 2003).

Still, some students were less compelled to always reposition themselves against Black male stereotypes on campus but instead chose to just be themselves irrespective of White fears. While discussing one of his photos (see figure 2) Reg explains that:

Personally, I really don't care. I'm gonna act the way I will act. I don't go around acting an ass or acting ignorant, but I'm not gonna hide me and hide my Blackness and what I love and who I am. I'm always the one to walk around campus with a Black power shirt on or something that represents or symbolizes my culture or my heritage.

\section{[Insert Figure 2 Here]}

In his photo Reg is participating in an on-campus silent march on Trayvon Martin's birthday, the unarmed Black teenager who was murdered by George Zimmerman in 2012 while returning home from a store having bought Arizona Iced Tea and Skittles. Trayvon's murder birthed the \#Blacklivesmatter movement and revitalized Black political consciousness among male youth like Reg. The photo is significant because it visually repositions Reg as unapologetically Black, which too is an act of subversion. The iconography of the Black power fist necklace, his shirt 
displaying the afro of a Black woman bearing the names of Black citizens murdered by the state, and the American flag covering the woman's mouth, are powerful images that assert Reg's burgeoning activist identity, masculinities of resistance, and alliance with a larger political movement. And though the constraints placed on Black male performances in predominantly White spaces seemingly produce the code switching and repositioning practices of some Black men, Reg and other men like him, resist these constraints by asserting their racial identity as a normalizing act of self-determination within particular moments. Collectively speaking, the different approaches to managing race among the participants are examples of the ways Black men respond to the racial climate of the university but also point to the diversity of Black masculinities in college (Feagin, Vera, and Imani 1996; Jackson and Wingfield 2013; Wilkins 2012a).

Responding to racism. Finally, the students also managed the racial climate by directly responding to racist events in various ways. When faced with a racialized event, the students would read the situation and decide whether to deflect the issue, exercise patience and educate, or confront the racist event directly. In most cases, the students were proactive in their responses and chose to respond through direct confrontation or education in order to achieve a resolution. Terrell explains that when his peers "throw out some stereotypes, I'm just like yeah, this isn't ok and I'll speak out about it." Similarly, Apollo provided detailed accounts of a series of events he responded to. In discussing his adjustment to campus life, he shared a photo of a defaced sign in his residence hall that initially read "Trigger Warning Language" (see figure 3) but was turned into a racial slur:

This was found on the second floor. I couldn't believe it, and this is when I was just adjusting to being here and standing out and this did not help...I hold it up to my RA. 
She was just like "throw it away." I'm like, "throw it away? Can I talk to you?" I was like “can you believe this?" She was like, “yeah, just throw it away, just get rid of it.” I was like, "no, this is a problem."

\section{[Insert Figure 3 Here]}

Apollo's plea for the issue to be escalated to the director was also dismissed. He continued in the interview by describing a racist event during his experience as a member of a predominantly White fraternity. He first described a fraternity chapter meeting where one of his brothers was singing a song that included the line "catch a nigger by its toe" and the anxiety he experienced as all his brothers stared at him for a reaction. He continued with the story explaining:

Then, next meeting, they pull out a Black dildo because there's a thing like if I or you do something wrong, you have to carry the Black dildo. If you don't have it, you get slapped with it next meeting. So, they pulled that out, and all eyes on me again...

Apollo met with the chapter president to voice his concern about the series of racist incidents and the chapter president placed the responsibility back onto Apollo to address the chapter. Apollo explained, "So that's what I did, I addressed it. I've never felt my heart beat so hard, just a room full of White guys talking about racism and the n word with the hard r's."

On one hand, these examples demonstrate the agency of Black men in responding to and resisting campus based racism. At the same time, the examples point to institutional failure in maintaining a positive campus climate for Black men. Harper and Hurtado (2007) describe such incidents as examples of institutional negligence regarding the university's racial commitments, and when students like Apollo attempt to communicate the nature of the racial climate to institutional figures, their concerns are sometimes justified away or completely ignored (Jones and Reddick 2017). Still, these examples of resistance are less documented in the literature on 
Black college masculinities but highlight the agency in how Black men respond to the racial microaggressions they experience on campus.

\section{Conclusion and Implications}

Research shows that repeated exposure to microaggression events on college campuses contributes to a poor campus climate, negative academic outcomes, and other psychological stressors (Smith, Hung, and Franklin 2011; Landrine and Klonoff 1996). These outcomes hinder student achievement and limit Black men's ability to reap the benefits of a college education. Furthermore, since universities are sites of reproduction, Black men not only encounter limitations on their social mobility, they also encounter the institutions socializing process as race-gendered bodies in predominantly White spaces. Thus, the campus racial climate contributes to particular types of racial and gender socialization for Black men.

As a numeric minority on campus, the men in this study described a less than welcoming racial climate, contending with both overt and subtle racism from their peers, faculty and law enforcement. In discussing their surveillance and feelings of (in)visibility, the students in this study described aspects of the campus racial climate as the context in which they learn and decide when and how to enact certain masculinities in particular moments. Furthermore, the surveillance and racial profiling of Black men on college campuses might also be understood intersectionally, as Black men are more likely to be surveilled and profiled because they are both Black and men and experience particular microaggressions at this intersection of race and gender.

Many of the race-gendered microaggression events experienced rely on hegemonic performativities of Black masculinity, and they are instances in which ontologies of Black male deviancy, sexuality and otherness are installed. In a society where racism is endemic, 
microaggression events on college campuses are then moments of racial and gender socialization where Black men learn how they are viewed and what they are assumed to be. These normalizing judgements are often resisted and subverted by Black men on college campuses (McGee and Martin 2011; Harper 2009) and the students in this study performed a range of masculinities in anticipation of and response to campus-based racism.

The particular subversive practices of code switching and repositioning, and the participants discussion of these practices, provides insight into the diversity of Black masculinities and sexualities on predominantly White campuses. Some of the Black men engage in code switching and repositioning more than others, though their behaviors should not be confused with attempts at assimilation. Others are less likely to code switch or reposition themselves all the time, but they do engage in these practices as needed. Instead, code switching and repositioning might be examples of subversive Black masculine performances that respond to and resist normalizing judgements in particular moments. By understanding racial stereotypes imposed upon them and through ritualized repetition (i.e. knowing when, how and if to switch or reposition), the students take up discursive spaces of liminality where subversive masculinities are enacted in particular moments and towards specific ends (Whitehead and Barrett 2001; Butler 1988; Gardiner 2005).

We also learned that race, gender, and sexuality intersect in similar but different ways for heterosexual and queer Black men in the study. While the misinterpretation of Black male behaviors as "aggressive" is a racial stereotype imposed upon both queer and heterosexual men, heterosexual men's "aggression" is viewed as a threat while queer Black men's "aggression" is dismissed as feminine, which presupposes a heteronormative performativity of masculine aggression that Black queer men are somehow transgressing. While race plays a central role in 
the gendered expectations and socialization of Black men on college campuses, attention must be paid to the ways that queer and heterosexual Black men encounter and respond to the university's racial climate in similar and divergent ways.

Still, though predominantly White universities are contested sites of gender socialization, where dominant ideologies of Black masculinities are imposed, the students in this study demonstrate the specific ways Black men make sense of the campus racial climate, and how they negotiate, subvert and resist dominant regimes of truth and the reproductive nature of schooling.

Implications. The disparities in the racialized experiences at predominantly White universities represent a particular opportunity gap for Black students, and though many Black men have developed resilient behaviors within hostile racial campus climates (Harper 2008; McGee and Martin 2011), colleges and universities should proactively work to improve the campus climate, educational, and social opportunities for Black men. A product of the college experience is the development of social capital. An important form of social capital involves meaningful peer-to-peer and student-faculty interactions. Universities should work towards creating intentional interactions among diverse students with purposeful dialogue around diversity and social justice issues. Additionally, faculty might engage in similar dialogues, and institutions could develop programming for intentional interactions and mentoring opportunities among faculty and diverse student populations.

Moreover, we should also build off the cultural wealth of Black men and leverage these assets with high impact practices (Yosso 2005). For instance, research shows that Black males with positive racial identity tend to be more resilient and have positive academic outcomes (Caughy et al. 2002; Friend, Hunter, and Fletcher 2011). The students in the current study are all high achievers and are on track to graduate. They also appear to have positive racial identity and 
are comfortable with themselves. Universities can support the positive racial identity development of all of their Black male students through the use of Black male initiatives. These initiatives are shown to foster student engagement, academic persistence, social integration, and research development of students (Wood and Palmer 2015).

The sample size, specificity of the location, and lack of generalizability are limitations to the study. Future research should continue to examine Black males attending liberal arts institutions as this is an understudied population but also one that tends to graduate at higher rates than their public university peers (Musu-Gillette et al. 2017). Additionally, more research should examine micro, meso and macro factors contributing to Black male success, with a focus on the lived experiences and insights of Black male achievers. Finally, there is a limited but growing body of research focused specifically on Black masculinities on college campus. The current study attempts to contribute to this gap in the literature but more work will need be done in documenting the diversity of Black masculinities and sexualities in college. 
Figure 1. Surveillance on campus

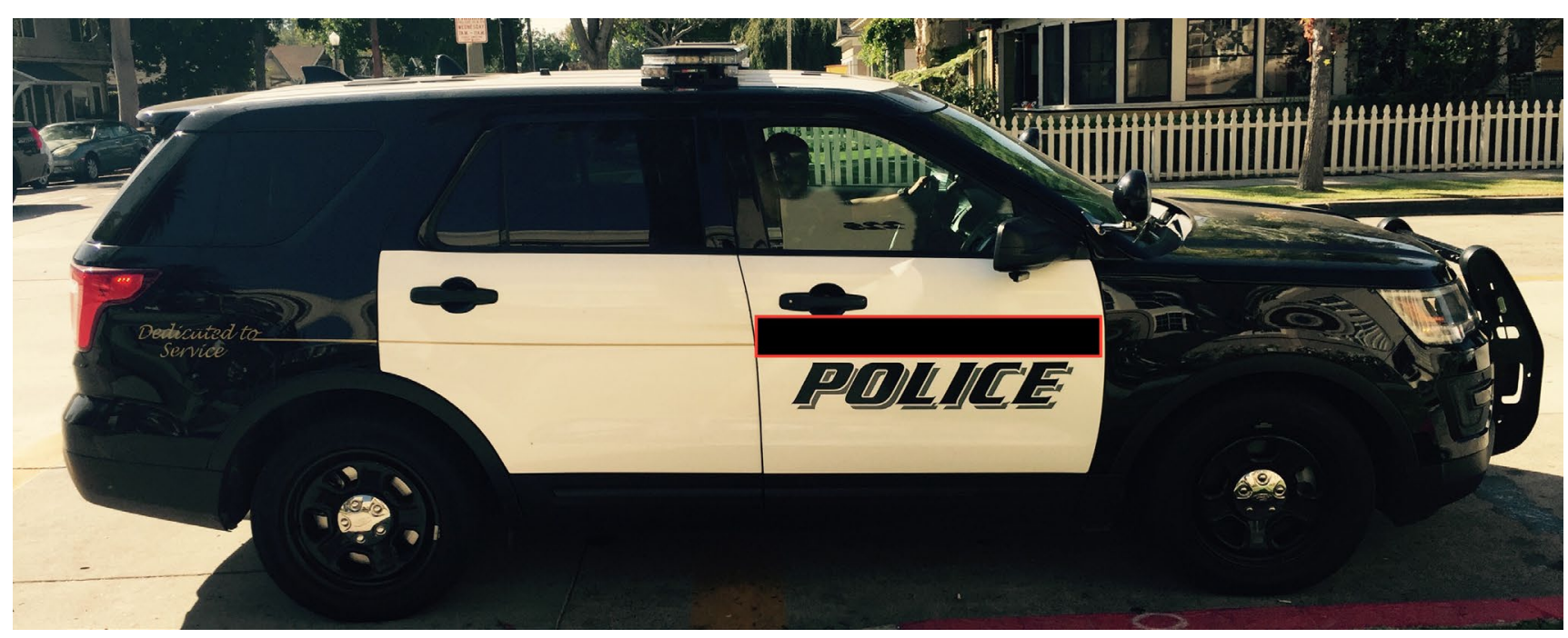


Figure 2. Reg at a silent march for Trayvon Martin

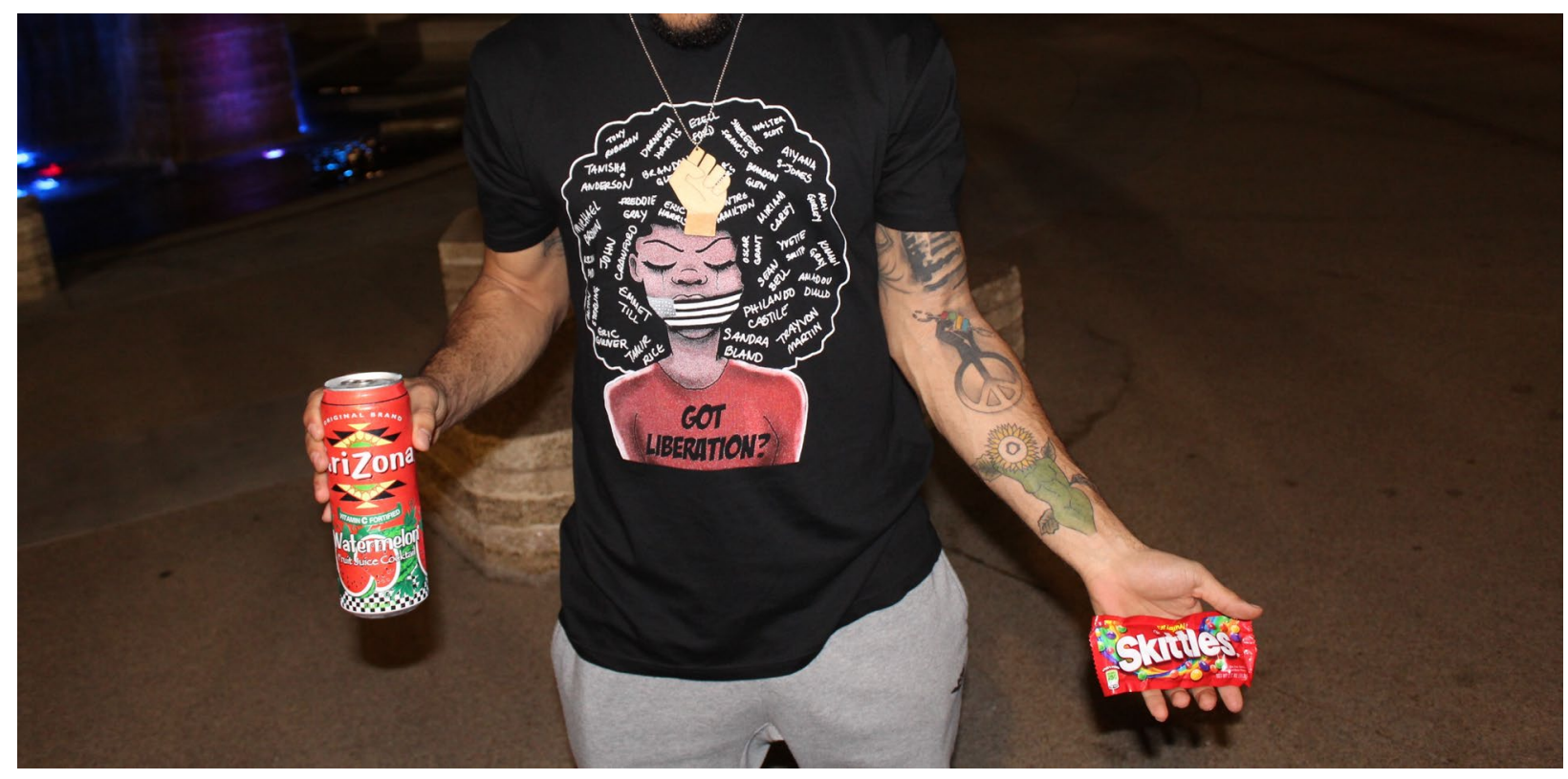


Figure 3. Apollo's photo in the residence hall

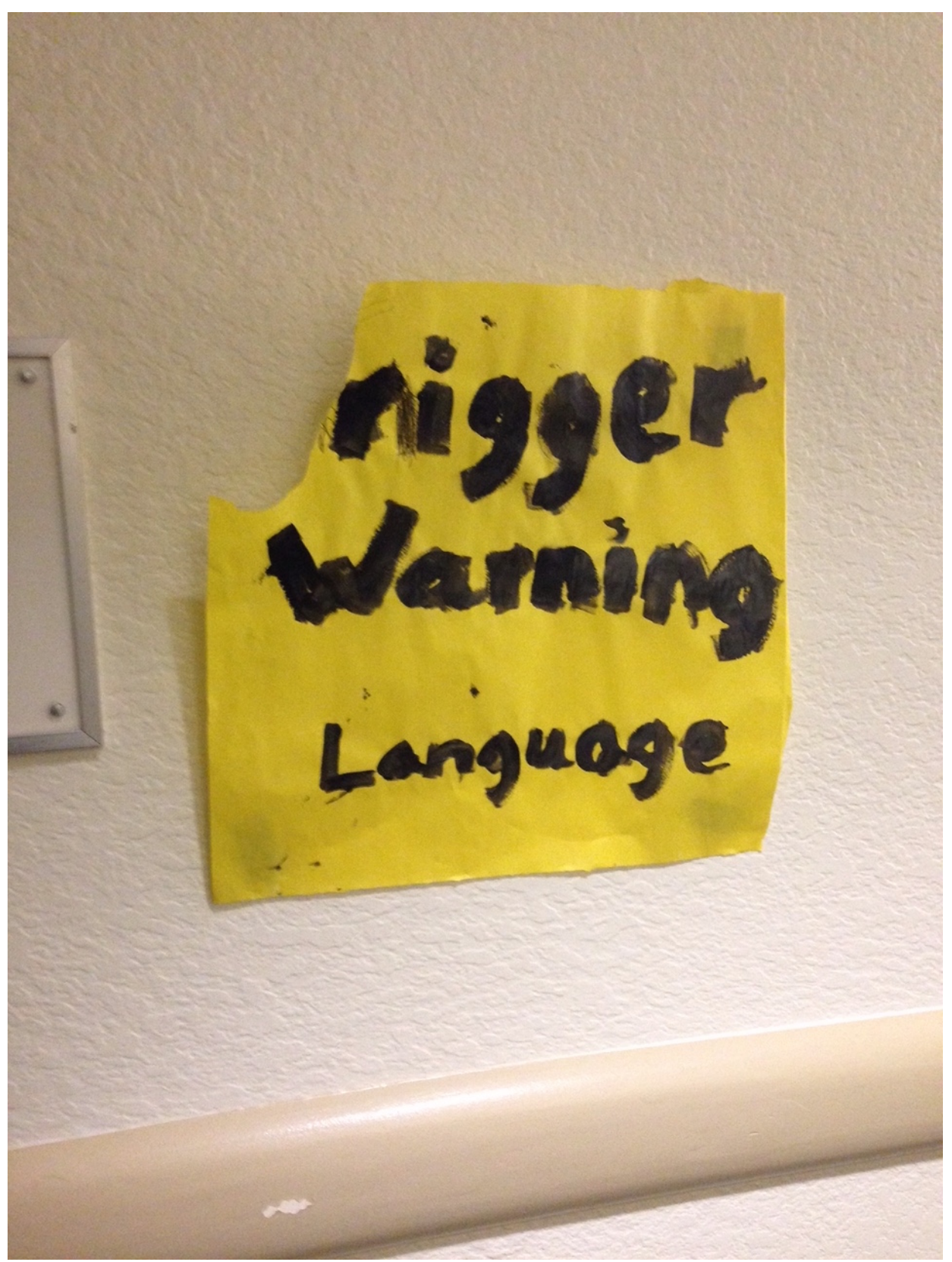




\section{References}

Bell, Derrick. 1992. Faces at the Bottom of the Well: The permanence of racism. New York: Basic Books.

Bonilla-Silva, Eduardo, and Tyrone A. Forman. 2000. "'I am not a racist but ...": mapping White college students' racial ideology in the USA." Discourse \& Society 11 (1):50-85.

Bourdieu, Pierre. 1977. "Cultural Reproduction and social reproduction." In Power and Ideology in Education, edited by Jerome Karabel and A.H. Halsey, 487 - 511. New York: Oxford University Press.

Butler, Judith. 1988. "Performative Acts and Gender Constitution: An Essay in Phenomenology and Feminist Theory." In, 519. Johns Hopkins University Press.

Caughy, Margaret O'Brien, Patricia J. O'Campo, Suzanne M. Randolph, and Kim Nickerson. 2002. "The Influence of Racial Socialization Practices on the Cognitive and Behavioral Competence of African American Preschoolers." Child Development 73 (5):1611 - 25.

Comeaux, Eddie. 2013. "Faculty Perceptions of High-Achieving Male Collegians: A Critical Race Theory Analysis." Journal of College Student Development 54 (5):453-65.

Crenshaw, Kimberlee. 1993. "Demarginalizing the Intersection of Race and Sex: A black feminist critique of antidiscrimination doctrine, feminist theory, and antiracist politics." In Feminist Legal Theory, edited by D. Kelley Weisberg. Philadelphia: Temple University Press.

D'Augelli, Anthony R., and Scott L. Hershberger. 1993. "African American Undergraduates on a Predominantly White Campus: Academic Factors, Social Networks, and Campus Climate." The Journal of Negro Education 62 (1):67-81. 
Dancy, T. Elon. 2011. "Colleges in the making of manhood and masculinity: gendered perspectives on African American males." Gender \& Education 23 (4):477-95.

Davis, James Earl. 2003. "Early Schooling and Academic Achievement of African American Males." Urban Education 38 (5):515 - 37.

Day, Kristen. 2006. "Being feared: masculinity and race in public space." Environment \& Planning A (3):569.

Erickson, Frederick. 1986. "Qualitative Methods in Research on Teaching." In Handbook of research on teaching, edited by Merlin C. Wittrock, 119 - 61. New York: MacMillan.

Feagin, Joe R. 1992. "The Continuing Significance of Racism: Discrimination Against Black Students in White Colleges." In, 546. Sage Publications.

Feagin, Joe R., Hernan Vera, and Nikitah Imani. 1996. The agony of education : Black students at white colleges and universities: New York : Routledge, 1996.

Fischer, Mary J. 2010. "A Longitudinal Examination of the Role of Stereotype Threat and Racial Climate on College Outcomes for Minorities at Elite Institutions." Social Psychology of Education: An International Journal 13 (1):19-40.

Foucault, Michel. 1979. "On Governmentality." Ideology and Consciousness 6:5 - 22.

Friend, Christian A., Andrea G. Hunter, and Anne C. Fletcher. 2011. "Parental Racial Socialization and the Academic Achievement of African American Children: A CulturalEcological Approach." Journal of African American Studies 15 (1):40-57.

Gardiner, Judith Kegan. 2005. "Men, Masculinities, and Femist Theory." In Handbook of Studies on Men and Masculinities, edited by Michael S. Kimmel, Jeff Hearn and R.W. Connell, 35 - 50. Thousand Oaks, CA: Sage Publications. 
Gleditsch, Rebecca Folkman, and Justin Allen Berg. 2017. "Racial Attitudes of University Faculty Members: Does Interracial Contact Matter?" Humboldt Journal of Social Relations 39:104-16.

Goetz, J.P., and Margaret D. LeCompte. 1984. Ethnography and Qualitative Design in Educational Research. Orlando, FL: Academic Press, Inc.

Goffman, Erving. 1959. The Presentation of Self in Everyday Life. Garden City, N.Y.: Doubleday.

Greene, Deric M., and Felicia R. Walker. 2004. "Recommendations to Public Speaking Instructors for the Negotiation of Code-Switching Practices among Black EnglishSpeaking African American Students." The Journal of Negro Education (4):435.

Hall, Stuart, Charles Critcher, Tony Jefferson, John Clarke, and Brian Robert. 1978. Policing the Crisis: Mugging, the state and law and order. London: Macmillan.

Harper, Shaun R. 2008. "Realizing the Intended Outcomes of Brown." American Behavioral Scientist 51 (7):1030-53.

_.2009. "Niggers no more: a critical race counternarrative on Black male student achievement at predominantly White colleges and universities." International Journal of Qualitative Studies in Education 22 (6):697-712.

Harper, Shaun R., and Sylvia Hurtado. 2007. "Nine Themes in Campus Racial Climates and Implications for Institutional Transformation." New Directions for Student Services (120):7-24 .

Harper, Shaun R., and Stephen John Quaye. 2007. "Student Organizations as Venues for Black Identity Expression and Development among African American Male Student Leaders." Journal of College Student Development 48 (2):127-44. 
Harris, Frank, Robert T. Palmer, and Laura E. Struve. 2011. "'Cool Posing" on Campus: A Qualitative Study of Masculinities and Gender Expression among Black Men at a Private Research Institution." The Journal of Negro Education 80 (1):47-62.

Harris, Whitney G. 2003. "African American Homosexual Males on Predominantly White College and University Campuses." Journal of African American Studies 7 (1):47-56.

Henry, Wilma J., Samantha R. Fowler, and Nicole M. West. 2011. "Campus Climate: An Assessment of Students' Perceptions in a College of Education." Urban Education 46 (4):689-718.

Hope, Elan C., Micere Keels, and Myles I. Durkee. 2016. "Participation in Black Lives Matter and deferred action for childhood arrivals: Modern activism among Black and Latino college students." Journal of Diversity in Higher Education 9 (3):203-15.

Howard, Tyrone C., Terry K. Flennaugh, and Clarence L. Terry Sr. 2012. "Black males, social imagery, and the disruption of pathological identities: Implications for research and teaching." Educational Foundations 26 (1):85-102.

Hurtado, Sylvia. 2015. "Thinking About Race: The Salience of Racial Identity at Two- and FourYear Colleges and the Climate for Diversity." The Journal of Higher Education (1):127.

Jackson, B. A., and A. H. Wingfield. 2013. "Getting Angry to Get Ahead: Black College Men, Emotional Performance, and Encouraging Respectable Masculinity." Symbolic Interaction 36 (3):275-92.

Johnson, Dawn R., Timothy H. Wasserman, Nilay Yildirim, and Barbara A. Yonai. 2014. "Examining the Effects of Stress and Campus Climate on the Persistence of Students of Color and White Students: An Application of Bean and Eaton's Psychological Model of Retention." Research in Higher Education 55 (1):75-100. 
Jones, Veronica A. veronica jones unt edu, and Richard J. Reddick. 2017. "The Heterogeneity of Resistance: How Black Students Utilize Engagement and Activism to Challenge PWI Inequalities." Journal of Negro Education 86 (3):204-19.

Karl, W. Reid. 2013. "Understanding the Relationships among Racial Identity, Self-Efficacy, Institutional Integration and Academic Achievement of Black Males Attending Research Universities." The Journal of Negro Education 82 (1):75-93.

Kim, Young K. 2010. "Racially Different Patterns of Student-Faculty Interaction in College: A Focus on Levels, Effects, and Causal Directions." Journal of the Professoriate 3 (2):16189.

Landrine, Hope, and Elizabeth A. Klonoff. 1996. "The Schedule of racist events: a measure of racial discrimination and a study of its negative physical and mental health consequences." Journal of Black Psychology (2):144.

Lewis, Amanda E., Mark Chesler, and Tyrone A. Forman. 2000. "The Impact of "Colorblind" Ideologies on Students of Color: Intergroup Relations at a Predominantly White University." The Journal of Negro Education 69 (1/2):74-91.

Lincoln, Yvonna S., and Egon G. Guba. 1985. Naturalistic Inquiry. Beverly Hills, CA: Sage Publications.

Majors, Richard, and Janet Mancini Billson. 1992. Cool Pose: The dilemmas of black manhood in America. New York: Touchstone.

Margolis, Eric. 2001. The Hidden Curriculum in Higher Education.

Margolis, Eric, and Luc Pauwels. 2011. "The SAGE Handbook of Visual Research Methods." In. Thousand Oaks, CA: Sage Publications. 
Marriott, David. 1996. "Reading Black Masculinities." In Understanding Masculinities, edited by Mairtin Mac an Ghaill, 185 - 201. Buckingham: Open University.

McClure, Stephanie M. 2006. "Improvising Masculinity: African American Fraternity Membership in the Construction of a Black Masculinity." Journal of African American Studies $10(1): 57-73$.

McGee, Ebony O., and Danny B. Martin. 2011. ""You would not believe what I have to go through to prove my intellectual value!": Stereotype management among academically successful Black mathematics and engineering students." American Educational Research Journal 48 (6):1347-89.

McGuire, K. M., J. Berhanu, C. H. F. Davis, and S. R. Harper. 2014. "In Search of Progressive Black Masculinities: Critical Self-Reflections on Gender Identity Development among Black Undergraduate Men." Men and Masculinities 17 (3):253-77.

Musu-Gillette, Lauren, Cristobal De Brey, Joel McFarland, William Hussar, William Sonnenberg, and Sidney Wilkinson-Flicker. 2017. "Status and trends in the education of racial and ethnic minorities." In. Washington, DC: U.S. Departmen of Education, National Center for Education Statistics.

Nadal, Kevin L., Marie-Anne Issa, Jayleen Leon, Vanessa Meterko, Michelle Wideman, and Yinglee Wong. 2011. "Sexual Orientation Microaggressions: "Death by a Thousand Cuts" for Lesbian, Gay, and Bisexual Youth." Journal of LGBT Youth 8 (3):234-59.

Noguera, Pedro A. 2003. "The Trouble with Black Boys: The role and influence of environmental and cultural factors on the academic performance of African American males." Urban Education 38 (4):431 - 59. 
Palmer, Robert, and Marybeth Gasman. 2008. ""It Takes a Village to Raise a Child": The Role of Social Capital in Promoting Academic Success for African American Men at a Black College." Journal of College Student Development 49 (1):52-70.

Park, Julie J., Nida Denson, and Nicholas A. Bowman. 2013. "Does Socioeconomic Diversity Make a Difference? Examining the Effects of Racial and Socioeconomic Diversity on the Campus Climate for Diversity." American Educational Research Journal 50 (3):466-96.

Pierce, C., J. Carew, D. Peirce-Gonzalez, and D. Willis. 1978. "An experiment in racism: TV commercials." In Television and Education, edited by C. Pierce, 62-88. Beverly Hills: Sage.

Saint-Aubin, Arthur F. 2002. "A Grammar of Black Masculinity: A body of science." The Journal of Men's Studies 10 (3):247 - 70.

Seidman, Irving E. 1991. Interviewing as Qualitative Research: A guide for researchers in education and social sciences. New York: Teachers College Press.

Shih, Margaret, Todd L. Pittinsky, and Nalini Ambady. 1999. "Stereotype Susceptibility: Identity Salience and Shifts in Quantitative Performance." Psychological Science 10 (1).

Shirazi, Roozbeh. 2016. "'These boys are wild': constructions and contests of masculinities at two Jordanian high schools." Gender \& Education 28 (1):89-107.

Smedley, Brian D., Hector F. Myers, and Shelly P. Harrell. 1993. "Minority-Status Stresses and the College Adjustment of Ethnic Minority Freshmen." The Journal of Higher Education $64(4): 434-52$.

Smith, William A., Man Hung, and Jeremy D. Franklin. 2011. "Racial Battle Fatigue and the MisEducation of Black Men: Racial Microaggressions, Societal Problems, and Environmental Stress." The Journal of Negro Education 80 (1):63-82. 
Smith, William A., Tara J. Yosso, and Daniel G. Solórzano. 2007. "Racial Primes and Black Misandry on Historically White Campuses: Toward Critical Race Accountability in Educational Administration." Educational Administration Quarterly 43 (5):559-85.

Solórzano, Daniel G., Walter R. Allen, and Grace Carroll. 2002. "Keeping Race in Place: Racial microaggressions and campus racial climate at the University of California, Berkeley." Chicano-Latino Review 23:15-67.

Solórzano, Daniel G., Miguel Ceja, and Tara Yosso. 2000. "Critical Race Theory, Racial Microaggressions, and Campus Racial Climate: The experiences of African American college students." The Journal of Negro Education 69 (1/2):60 - 73.

Solórzano, Daniel G., and Tara J. Yosso. 2002. "Critical Race Methodology: CounterStorytelling as an Analytical Framework for Education Research." Qualitative Inquiry 8 (1):23-44.

St. John, Craig, and Tamara Heald-Moore. 1995. "Fear of Black strangers." Social Science Research 24 (3):262-80.

Steele, Claude M. 1997. "A Threat in the Air: How stereotypes shape intellectual identity and performance." American Psychologist 52 (6):613 - 29.

Strayhorn, Terrell L. 2010. "When Race and Gender Collide: Social and Cultural Capital's Influence on the Academic Achievement of African American and Latino Males." Review of Higher Education (4).

Strayhorn, Terrell L., and Derrick L. Tillman-Kelly. 2013. "Queering Masculinity: Manhood and Black Gay Men in College." Spectrum: A Journal on Black Men (2):83.

Strong, Wesley. 2013. "CHAPTER TWO: Repression of Student Activism on College Campuses." Counterpoints 410:15-27. 
Turner, Caroline Sotello Viernes. 1994. "Guests in Someone Else's House: Students of Color." Review of Higher Education 17 (4):355-70.

Waiwaiole, Evelyn N., E. Michael Bohlig, and Kristine J. Massey. 2016. "Student Success: Identifying High-Impact Practices." New Directions for Community Colleges (175):4555.

Wang, Caroline, and Mary Ann Burris. 1997. "Photovoice: Concept, Methodology, and Use for Participatory Needs Assessment." Health Education \& Behavior 24 (3):369-87.

Whitehead, Stephen M., and Frank Barrett. 2001. "The Sociology of Masculinity." In The Masculinities Reader, edited by Stephen M. Whitehead and Frank Barrett, 1 - 26. Cambridge, England: Polity Press.

Wilkins, Amy C. 2012a. ""Not Out to Start a Revolution": Race, Gender, and Emotional Restraint among Black University Men." Journal of Contemporary Ethnography 41 $(1): 34-65$.

_. 2012b. "Stigma and status: Interracial intimacy and intersectional identities among Black college men." Gender \& Society 26 (2):165-89.

Wood, J. Luke, and Robert T. Palmer. 2015. Black Men in Higher Education: A Guide to Ensuring Student Success. New York, NY: Routledge.

Woodford, Michael R., Michael L. Howell, Alex Kulick, and Perry Silverschanz. 2013. "'That's so Gay": Heterosexual Male Undergraduates and the Perpetuation of Sexual Orientation Microagressions on Campus." Journal of Interpersonal Violence 28 (2):416-35.

Yosso, Tara J. 2005. "Whose Culture Has Capital?: A critical race theory discussion of community cultural wealth." Race Ethnicity and Education 8 (1):69-91. 